\title{
The Repression of Cell Wall- and Plastid-Related Genes and the Induction of Defense-Related Genes in Rice Plants Infected with Rice dwarf virus
}

\author{
Takumi Shimizu, ${ }^{1}$ Kouji Satoh, ${ }^{2}$ Shoshi Kikuchi, ${ }^{2}$ and Toshihiro Omura ${ }^{1}$ \\ ${ }^{1}$ Research Team for Vectorborne Diseases, National Agricultural Research Center, Kannondai 3-1-1, Tsukuba, \\ Ibaraki 305-8666, Japan; ${ }^{2}$ Plant Genome Research Unit, National Institute of Agrobiological Sciences, Kannondai 2-1-2, \\ Tsukuba, Ibaraki 305-8602, Japan
}

Submitted 20 July 2006. Accepted 5 October 2006.

\begin{abstract}
An analysis, using microarrays, of gene expression in rice plants infected with Rice dwarf virus revealed significant decreases in levels of expression of genes that are involved in the formation of cell walls, reflecting the stunted growth of diseased plants. The expression of plastid-related genes also was suppressed, as anticipated from the white chlorotic appearance of infected leaves. By contrast, the expression of defense- and stress-related genes was enhanced after viral infection. These results suggest that virusinfected rice plants attempt to survive viral infection and replication by raising the levels of expression of defenseand stress-related genes while suppressing the expression of genes required for the elongation of cells and photosynthesis.
\end{abstract}

Viruses can alter the transcriptional networks of their hosts. These alterations are caused by the direct and indirect effects of viral replication that result in the development of disease (Hull 2002). Thus, the characterization of virally induced changes in expression of host genes provides valuable insight into the host's response to viral activity. The use of microarrays to profile gene expression provides a global view of the changes in gene expression that occur upon the cell's exposure to a stimulus, such as viral infection (Rensink and Buell 2005). Oligonucleotide-based microarrays, based on genome-wide sequence information (Arabidopsis Genome Initiative 2000; International Rice Genome Sequencing Project 2005), have greater specificity and higher quantitative accuracy than spottedcDNA microarrays, and such microarrays have been developed for rice, a major food crop. Changes in gene expression in virus-infected rice plants have never been investigated, to our knowledge, despite the significant impact of the viral infection of rice on food production.

The factors responsible for establishment of the successful viral infection of plants, via their effects on viral replication, and the establishment of or changes in plant defenses upon infection remain poorly understood (Maule et al. 2002). Despite

Corresponding author: T. Omura; Telephone: +81-29-838-8932; Fax: +8129-838-8929; E-mail: toomura@ affrc.go.jp

All microarray data from this work are available in the NCBI Gene Expression Omnibus (GEO) database as accession number GSE5286.

* The $\boldsymbol{e}$-Xtra logo stands for "electronic extra" and indicates the HTML abstract available on-line contains supplemental material not included in the print edition. Four supplemental tables are published on-line. advances in the identification of changes in the expression of plant genes in response to the infection of dicotyledonous plants by plus-strand RNA viruses (Golem and Culver 2003; Marathe et al. 2004; Whitham et al. 2003), similar studies have not been conducted, to our knowledge, with viruses that infect monocotyledonous plants, such as rice. This deficit is due, in part, to the difficulties associated with investigations of rice viruses, most of which are transmitted by vector insects, which are not easy to handle.

Rice dwarf virus (RDV) is one of the viruses that cause the most economic damage to crop plants in northern Asian countries. RDV cannot be transmitted mechanically and is transmitted to rice plants exclusively by insect vectors, in particular leafhoppers (Nephotettix spp.), after multiplication of the virus in the insect. Infection of rice plants by RDV leads to the appearance of white chlorotic specks on leaves and stunting of plant growth, which result in considerable decreases in grain yield.

RDV, which belongs to the genus Phytoreovirus in the family Reoviridae, is an icosahedral double-shelled particle of approximately $70 \mathrm{~nm}$ in diameter (Omura and Yan 1999). Twelve segments of double-stranded RNA (namely, the genome) and three species of protein are encapsidated with a thin layer of the core capsid protein P3. The core is further encapsidated by the outer capsid proteins $\mathrm{P} 2, \mathrm{P} 8$, and $\mathrm{P} 9$. The structural organization of the two major capsid proteins, P3 and P8, has been studied at the atomic level (Hagiwara et al. 2004; Miyazaki et al. 2005; Nakagawa et al. 2003). Moreover, the roles of the nonstructural proteins after infection of insect vector cells, as well as in infected plant cells, have been well characterized (Wei et al. 2006a, b, and c). Some of these structural and nonstructural proteins are considered to be targets for recognition by host rice plants to elicit the responses of infected plants that include the induction of the expression of factors that mediate viral infection, multiplication, and movement. However, host responses to viral infection remain poorly understood.

In this study, we investigated changes in gene expression in rice plants exposed to RDV to gain some insight into the fundamental physiological and biochemical changes that are induced by viral infection, in the hope of finding clues that might help to control the viral disease. We found that levels of expression of approximately 700 of the approximately 22,000 rice genes on the microarray changed more than twofold in RDV-infected rice plants. We discuss our results in terms of predicted physiological changes in the host plant upon infection by RDV. 


\section{RESULTS}

Symptom development and anatomical observations.

The earliest symptoms, white chlorotic specks (Fig. 1B), in newly developed leaves appeared at approximately 9 days post inoculation (dpi), but never were observed on inoculated leaves on which viruliferous insects were released. The newly developed leaves also exhibited the first symptom of stunting, showing that the leaf sheath did not extend beyond the former ones; thus, plants were no more elongated. Stunting symptoms became notable 20 dpi and later, when healthy plants extended leaves and leaf sheaths (Fig. 1A).

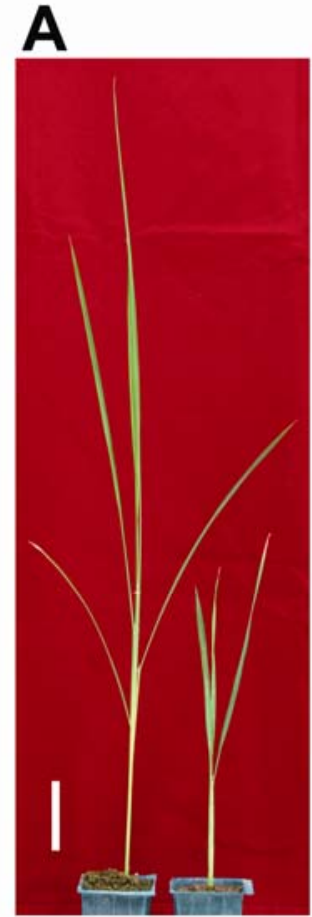

Mock RDV
B

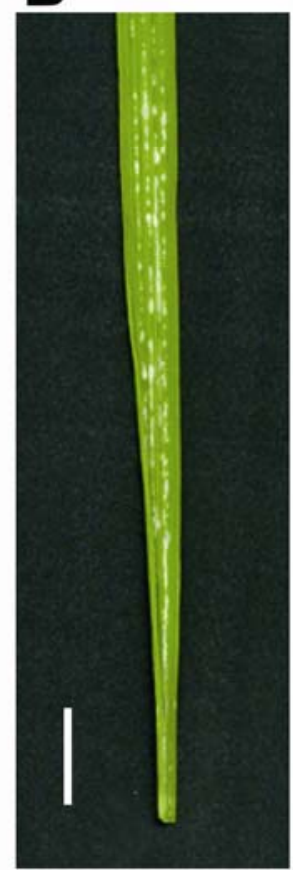

RDV-infected
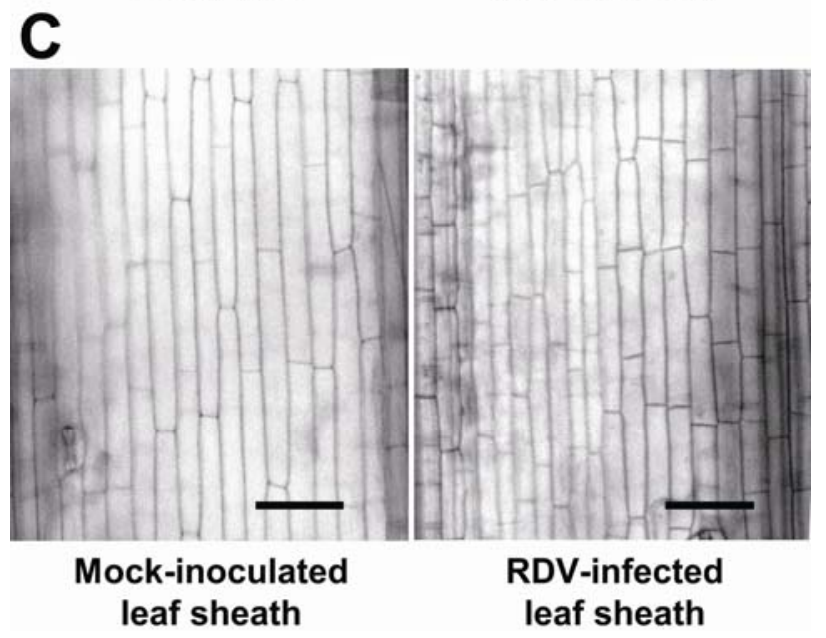

\section{RDV-infected} leaf sheath

Fig. 1. Typical symptoms of rice plants infected with Rice dwarf virus (RDV). After inoculation using viruliferous insects, plants were grown in an air-conditioned greenhouse. Mock = plants released with virus-free insects in the same manner as viral inoculation. A, Stunted RDV-infected rice plant (right) is shown next to a mock-inoculated rice plant (left) 20 days post inoculation (dpi). Bar $=5 \mathrm{~cm}$. B, Newly developed leaf from an RDV-infected rice plant 9 dpi with white chlorotic specks. Bar $=5 \mathrm{~mm}$. C, Light micrographs of RDV-infected and mock-inoculated leaf sheaths that were sectioned longitudinally. The leaf sheaths just under the fourth leaves of RDV-infected (right) and mock-inoculated (left) rice plants 20 dpi were sectioned. Bars $=100 \mu \mathrm{m}$.
We examined leaves to determine the cause of the stunting induced by RDV infection. When we compared leaf sheaths just under the fourth leaf of RDV-infected and mock-inoculated plants $20 \mathrm{dpi}$, we found that cells in RDV-infected plants were shorter (by 60\%) than those in mock-inoculated plants (Fig. 1C).

\section{Microarray analysis of gene expression in $\mathrm{RDV}$-infected rice plants.}

We collected plant materials at $9 \mathrm{dpi}$, the earliest time that infection can be confirmed by the appearance of symptoms and also the latest time to detect changes in gene expression that caused the symptom appearance on newly developed leaves, because symptoms that developed on leaves afterward were the same as those on the first leaf with symptoms 9 dpi.

To reduce experimental variations, four sets of 10 seedlings were harvested from RDV-infected and mock-inoculated plants. Total RNA was prepared from the four replicate sets of the pooled samples (Table 1; biological replicates 1 through 4).

To obtain a global picture of changes in gene expression in response to inoculation of rice plants with RDV, four replicates were carried out: three sets (Table 1, microarrays 1, 3, and 4) using RNAs from biological replicates 1 to 3 and one dye-swapping microarray (Table 1, microarray 2) using RNAs from biological replicate 1 as a technical replication. RNA was analyzed using the Agilent rice oligo-DNA array, which contains probe sets for 21,495 rice genes. The Agilent microarray software (Feature Extraction ver. 8.1.1.1) also was used to analyze the reliability of signals for each probe set and to assess changes in levels of RNA in response to RDV (i.e., induction or repression).

RDV-responsive genes were identified by applying the following selection criteria: (i) gene expression was detected at a statistically significant level in all four sets of microarray data, (ii) the change in gene expression occurred in the same direction (increase or decrease) in all four microarray analyses, and (iii) the average of the ratio (fold change; RDV infection/mock inoculation) of the levels of expression in all four microarray analyses was greater than 2.0 or less than 0.5 . Applying these criteria, we identified 188 genes with increased levels of expression and 498 with decreased levels. We considered these genes to be RDV-regulated genes and subjected them to further analysis. Information from the Knowledge-Based Oryza Molecular Biological Encyclopedia (KOME) database (Rice Full-Length cDNA Consortium 2004) was used to identify or to assign a putative function to each RDV-regulated gene.

\section{Metabolic pathways.}

To overview metabolic pathways influenced by RDV infection, genes related to the pathways were selected according to RiceCyc DB in GRAMENE (Jaiswal et al. 2006). In 22,000 array-spotted genes, 1,756 genes were related to the metabolic

Table 1. Details of experiments

\begin{tabular}{lclll}
\hline & & & \multicolumn{2}{c}{ Labeling } \\
\cline { 4 - 5 } Replicate $^{\mathbf{a}}$ & dpi $^{\mathbf{b}}$ & Method & Cy3 & Cy5 \\
\hline 1 & 9 & Microarray 1 & Mock & RDV \\
& $\ldots$ & Microarray 2 & RDV & Mock \\
2 & 9 & Microarray 3 & Mock & RDV \\
3 & 9 & Microarray 4 & Mock & RDV \\
4 & 9 & RT-PCR & $\ldots$ & $\ldots$ \\
\hline
\end{tabular}

${ }^{a}$ Each biological replicate represents mRNA isolated from 10 Rice dwarf virus (RDV)-infected or mock-inoculated plants.

${ }^{\mathrm{b}}$ Days post inoculation.

${ }^{c}$ Reverse-transcription polymerase chain reaction. 
pathways and the number of differentially expressed genes was 95, among which 76 genes (approximately 80\%) were suppressed. The expression of genes for carbon metabolismrelated pathways generally was influenced by RDV infection. Among the genes whose expression was suppressed, we focused on two functional categories, encoding cell wall- and plastid-related proteins, as described below.

\section{Cell wall-related genes.}

The most affected or influenced pathway was the cell wallrelated pathway (PRIMARY-CELL-WALL and SECONDARYCELL-WALL). The ratio of suppressed genes in cell wallrelated pathway was approximately $20 \%$ (Fig. 2), the highest value among all pathways.

The genes related to the synthesis of cell walls whose expression was suppressed in RDV-infected plants are shown in Table 2. They include genes for structural proteins (e.g., leucinerich repeat extensins [AK071989, AK061301, AK066703, and AK105020], proline-rich proteins [AK062795, AK061576, AK061529, AK060752, and AK100217], glycine-rich proteins [AK058218 and AK063637], and arabinogalactan proteins [AK104655, AK105603, and AK108308]). The expression of many genes for enzymes involved in the synthesis of cell walls also was suppressed; for example, genes for cellulose synthases (AK067424, AK100475, AK072356, AK073561, AK100523, and AK072259), endo-1,3-1,4- $\beta$-glucanases (AK063126, AK065044, AK059739, AK067264, AK073110, AK099698, AK100449, and AK070408), and pectin methylesterase (AK101962).

\section{Plastid-related genes.}

One of the typical symptoms induced by RDV infection was the appearance of white chlorotic specks on leaves; therefore, it was considered that the plastid formation was damaged by virus infection. All the differentially expressed genes in the chlorophyll synthesis pathway registered in HEME-SYN were suppressed by virus infection.

The plastid-related genes whose expression was suppressed are listed in Table 3 . They include the genes for chlorophyll a/b-binding protein (AK058289), the $\alpha$ subunit of rubisco subunit binding-protein (AK100602 and AK061410), and proteins in the $30 \mathrm{~S}$ ribosomal subunit of chloroplasts (AK099298 and AK062461) and in the 50S ribosomal subunit of chloroplasts (numerous genes).
Defense- and stress-related genes.

By contrast to the genes described above, the genes whose expression was enhanced included defense- and stress-related genes. The genes related to resistance to disease included genes for pathogenesis-related (PR) proteins (for example, PR1a [AK107926], ß-1,3-glucanases [AK070056, AK104862, AK104472, AK071889, and AK067528], chitinases [AK061042, AK060363, AK071013, AK100973, AK059767, AK102505, AK099355, AK060033, and AK106178], PR4 [AK063234], and thaumatin-like protein [AK102970]), WRKY transcription factors (AK108522, AK101653, AK103696, and AK109568), and stress-response proteins, such as glutathione $S$-transferases (AK064650, AK108376, and AK107822), peroxidases (AK067416, AK073202, and AK069456), and heatshock proteins (AK068186, AK064436, and AK071240) (Table 4).

Analysis by reverse-transcription-

polymerase chain reaction of representative genes.

Cross-hybridization due to closely related members of gene families can complicate the analysis of results of microarray analyses; therefore, we performed reverse-transcription polymerase chain reaction (RT-PCR) to verify our hybridization data. We examined the expression of 19 randomly selected genes from the microarray analysis, including genes whose expression was enhanced and those whose expression was suppressed. The RNA used in this analysis was isolated independently from RDV-infected and mock-inoculated plants from the fourth biological replicate (Table 1). The optimal numbers of reaction cycles for amplification by PCR were determined in preliminary analyses by gel electrophoresis. The results obtained by RT-PCR coincided well with the profiles of expression obtained by microarray hybridizations (Fig. 3).

\section{DISCUSSION}

In compatible hosts, viral invasion triggers numerous biochemical and physiological changes in cells, tissues, and even whole plants (Maule et al. 2002). Among these are local and systemic changes in host gene expression. Some local changes occur in the cells where viruses are actively replicating and include both induction and shutoff of host gene expression (Aranda et al. 1996; Escaler et al. 2000; Havelda and Maule 2000; Wang and Maule 1995). Other local changes in gene

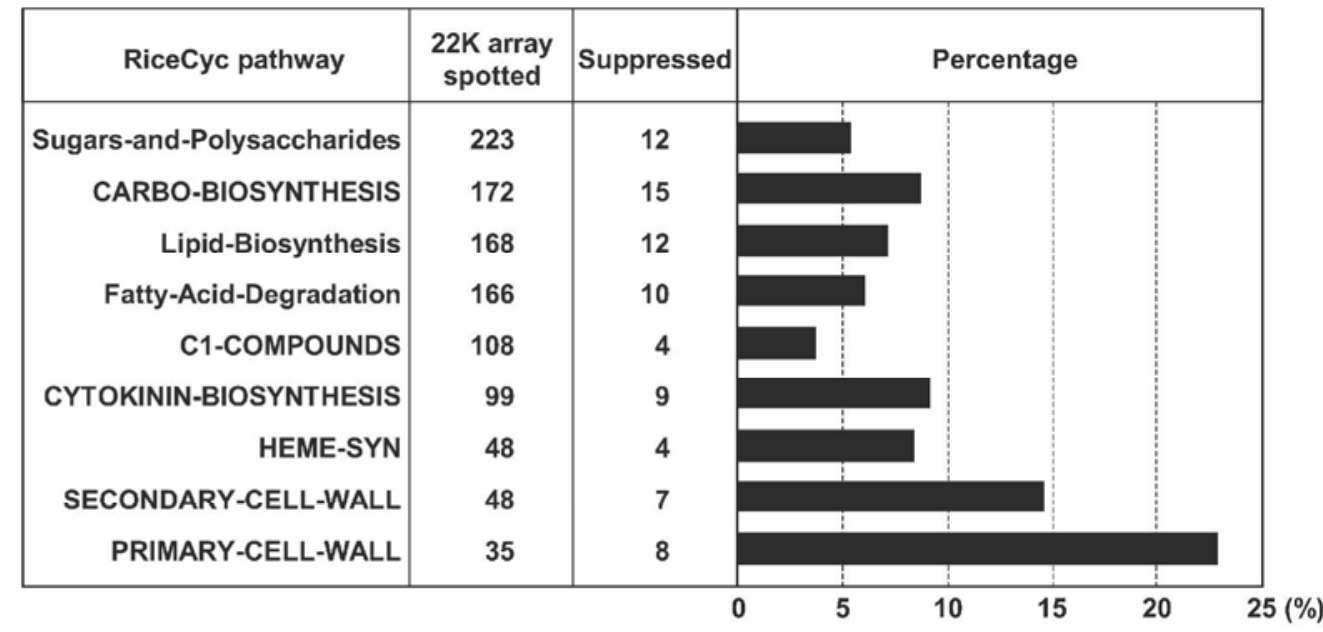

Fig. 2. Representative metabolic pathways suppressed by Rice dwarf virus (RDV) infection. RiceCyc pathway = all RiceCyc DB pathways were retrieved from RiceCyc release 1.0;22,000 array spotted = number of genes located in various pathways in 22,000-array spotted genes; Suppressed = number of genes with suppressed levels of expression by RDV infection; Percentage = percentage of the number of genes with suppressed levels of expression by RDV infection/number of 22,000-array spotted genes located in various pathways. 
expression can happen in advance of or behind the viral replication front (Havelda and Maule 2000). These virus-induced modifications in gene expression in infected dicotyledonous plants occur transiently and concomitantly with viral replication as it spreads cell-to-cell away from the site of inoculation. In the monocotyledonous rice plant-viruliferous insect inoculation system, insects released on healthy plants sit on any part of the plant; therefore, observers are unable to specify the portion of infection and where host gene response against viral infection occurs. Thus, we have used the entire aerial portion at the time of the first symptom appearance, and we obtained similar results in four microarray repetitions.

One of the notable changes that we found in the gene expression of RDV-infected rice plants was the significant repression of the expression of the genes for proteins involved in the synthesis of cell walls (Table 2). In general, the cell wall is the major determinant of cell morphogenesis in plants. The enlargement of cells depends on the tightly regulated expansion of the wall that surrounds each cell. The expression of genes for many of the key enzymes (Somerville et al. 2004; Yokoyama and Nishitani 2004) that are involved in the synthesis and remodeling of cell walls, such as cellulose synthase and $\beta$-1,3-1,4-glucanase, was significantly repressed by RDV infection. Moreover, the expression of genes for structural proteins of the cell wall, such as extensin, proline-rich proteins, glycine-rich proteins, and arabinogalactan proteins, was markedly suppressed. Extensin is one of the proteins that control morphogenesis and the shape of plant cells (Baumberger et al. 2001). The suppression of the elongation of leaf sheath cells (Fig. 1) and of the expression of cell wall-related genes in RDV-infected plants suggests that the typical dwarfing caused by RDV infection might be due to the repression by RDV of the expression of many cell wall- and cell elongation-related genes.

It was reported recently that expression of the gene for entkaurene oxidase, a gibberellin-biosynthetic enzyme, is repressed in RDV-infected rice plants (Zhu et al. 2005). However, we did not observe a significant change in expression of such genes under our inoculation conditions. On the other hand, the level of expression of the OsDWARF gene (AK101670), which encodes brassinosteroid-6-oxidase, a brassinosteroid biosynthetic enzyme, was 2.7-fold lower in infected than in mock-inoculated rice plants. The severe stunting of osdwarf mutant rice plants (Hong et al. 2002; Mori et al. 2002) is in harmony with

Table 2. Cell wall-related genes whose expression was suppressed by Rice dwarf virus (RDV) 9 days after inoculation of rice plants

\begin{tabular}{|c|c|c|c|c|c|c|}
\hline \multirow[b]{2}{*}{ Classification, GenBank no. } & \multirow[b]{2}{*}{ Annotation } & \multicolumn{5}{|c|}{ Fold change $^{a}$} \\
\hline & & Ave. & Slide 1 & Slide 2 & Slide 3 & Slide 4 \\
\hline \multicolumn{7}{|l|}{ Polysaccharide synthesis } \\
\hline AK067424 & Cellulose synthase-like protein & -7.88 & -8.18 & -6.25 & -11.81 & -7.09 \\
\hline AK 100475 & Cellulose synthase (CesA-2) & -3.85 & -5.22 & -3.13 & -4.79 & -3.14 \\
\hline AK072356 & Cellulose synthase (CesA-9) & -2.06 & -2.43 & -2.13 & -2.81 & -1.42 \\
\hline AK073561 & Cellulose synthase (CesA-7) & -2.09 & -2.54 & -1.92 & -2.60 & -1.64 \\
\hline AK 100523 & Cellulose synthase (CSLF2) & -2.02 & -2.53 & -2.12 & -2.07 & -1.59 \\
\hline AK072259 & Cellulose synthase & -2.03 & -2.22 & -2.20 & -1.88 & -1.87 \\
\hline \multicolumn{7}{|l|}{ Reassembly } \\
\hline AK059794 & $\beta$-Galactosidase & -3.88 & -5.55 & -4.68 & -5.24 & -2.24 \\
\hline AK102192 & $\beta$-Galactosidase & -4.14 & -4.11 & -4.10 & -6.34 & -3.12 \\
\hline AK102756 & $\beta$-Galactosidase & -3.29 & -3.44 & -2.56 & -4.30 & -3.32 \\
\hline AK059595 & Polygalacturonase (GH28) & -4.02 & -4.17 & -4.64 & -4.11 & -3.38 \\
\hline AK058942 & Polygalacturonase (GH28) & -2.51 & -2.44 & -2.33 & -2.47 & -2.87 \\
\hline AK102185 & Glycoside hydrolase (family $17 ;$ GH17) & -3.32 & -3.10 & -3.08 & -4.28 & -3.09 \\
\hline AK066336 & Glycoside hydrolase (family 1; GH1) & -3.05 & -4.08 & -3.14 & -2.45 & -2.94 \\
\hline AK067934 & Glycoside hydrolase (family $1 ; \mathrm{GH} 1$ ) & -2.76 & -2.58 & -2.19 & -3.30 & -3.34 \\
\hline AK063126 & Endo-1,3-1,4- $\beta$-glucanase & -7.31 & -6.74 & -7.95 & -7.64 & -7.01 \\
\hline AK065044 & Endo-1,3-1,4- $\beta$-glucanase & -3.07 & -3.15 & -2.18 & -3.43 & -4.22 \\
\hline AK059739 & Endo-1,3-1,4- $\beta$-glucanase & -2.94 & -3.42 & -2.87 & -2.90 & -2.68 \\
\hline AK067264 & Endo-1,3-1,4- $\beta$-glucanase & -2.84 & -3.28 & -2.95 & -2.87 & -2.40 \\
\hline AK073110 & Endo-1,3-1,4- $\beta$-glucanase & -2.58 & -2.65 & -2.94 & -2.07 & -2.85 \\
\hline AK099698 & Endo-1,3-1,4- $\beta$-glucanase & -2.17 & -2.63 & -2.66 & -2.39 & -1.50 \\
\hline AK100449 & Endo-1,3-1,4- $\beta$-glucanase & -2.27 & -2.38 & -2.49 & -2.36 & -1.95 \\
\hline AK070408 & Endo-1,3-1,4- $\beta$-glucanase & -2.19 & -2.72 & -1.94 & -2.67 & -1.76 \\
\hline AK101782 & $\alpha$-L-arabinofuranosidase & -14.54 & -15.27 & -10.25 & -17.46 & -18.23 \\
\hline AK060609 & Pectate lyase & -5.18 & -6.08 & -5.53 & -5.79 & -3.94 \\
\hline AK109490 & Pectin lyase-like protein & -2.15 & -2.04 & -2.29 & -2.57 & -1.85 \\
\hline AK106869 & Putative pectinesterase & -5.09 & -5.22 & -4.72 & -5.34 & -5.12 \\
\hline AK101962 & Putative pectin methylesterase & -3.24 & -2.78 & -2.98 & -3.35 & -4.12 \\
\hline \multicolumn{7}{|l|}{ Structural proteins } \\
\hline AK071989 & Leucine-rich repeat extensin & -35.32 & -26.39 & -32.46 & -46.29 & -43.55 \\
\hline AK061301 & Leucine-rich repeat extensin & -11.58 & -11.47 & -8.11 & -13.56 & -16.37 \\
\hline AK066703 & Leucine-rich repeat extensin & -11.57 & -12.06 & -8.63 & -12.95 & -14.33 \\
\hline AK 105020 & Leucine-rich repeat extensin & -3.61 & -3.53 & -4.08 & -4.07 & -2.99 \\
\hline AK062795 & Proline-rich protein (OsPRP1) & -63.39 & -69.41 & -75.70 & -59.83 & -53.29 \\
\hline AK061576 & Proline-rich protein (OsPRP2) & -7.65 & -9.27 & -12.37 & -5.86 & -6.11 \\
\hline AK061529 & Proline-rich protein & -3.54 & -5.16 & -4.81 & -3.70 & -2.18 \\
\hline AK060752 & Proline-rich protein & -3.26 & -2.94 & -2.45 & -3.55 & -5.10 \\
\hline AK100217 & Proline-rich protein & -2.64 & -2.62 & -3.08 & -2.28 & -2.67 \\
\hline AK058218 & Glycine-rich protein (ortholog of Zea mays ZmGR1a) & -26.57 & -23.38 & -21.10 & -31.22 & -35.30 \\
\hline AK063637 & Glycine-rich protein (OSGRP1) & -5.59 & -7.79 & -6.69 & -5.52 & -3.89 \\
\hline AK104655 & Arabinogalactan-protein & -13.46 & -15.34 & -12.08 & -14.22 & -12.66 \\
\hline AK105603 & Arabinogalactan protein & -6.66 & -7.95 & -7.64 & -6.73 & -5.11 \\
\hline AK108308 & Arabinogalactan protein & -4.14 & -4.71 & -5.13 & -4.52 & -2.97 \\
\hline
\end{tabular}

${ }^{\text {a }}$ Fold change $=($ normalized signal intensity of mock inoculated $) /($ normalized signal intensity of RDV infected $)$. 
Table 3. Plastid-related genes whose expression was suppressed by Rice dwarf virus (RDV) 9 days after inoculation of rice plants

\begin{tabular}{|c|c|c|c|c|c|c|}
\hline \multirow[b]{2}{*}{ GenBank no. } & \multirow[b]{2}{*}{ Annotation } & \multicolumn{5}{|c|}{ Fold change $^{a}$} \\
\hline & & Ave. & Slide 1 & Slide 2 & Slide 3 & Slide 4 \\
\hline AK073762 & 20-kDa chaperonin (protein Cpn21) (chloroplast precursor) & -8.73 & -8.44 & -8.98 & -8.01 & -9.65 \\
\hline AK066409 & Chloroplast nucleoid DNA-binding protein & -5.68 & -3.64 & -8.76 & -6.79 & -5.95 \\
\hline AK071888 & 3-Oxoacyl-(acyl-carrier-protein) synthase I (chloroplast precursor) & -4.67 & -5.28 & -4.44 & -5.25 & -3.97 \\
\hline AK061531 & Omega-3 fatty acid desaturase (chloroplast precursor) & -3.60 & -3.73 & -3.37 & -3.67 & -3.66 \\
\hline AK058289 & Chlorophyll a/b-binding protein 2 (chloroplast precursor) & -2.82 & -3.55 & -2.14 & -2.89 & -3.09 \\
\hline AK072228 & Chloroplast nucleoid DNA-binding protein & -2.85 & -2.66 & -3.26 & -3.00 & -2.57 \\
\hline AK063551 & Thylakoid lumenal 19.6-kDa protein (chloroplast precursor) & -2.79 & -2.79 & -2.48 & -2.94 & -3.00 \\
\hline AK109412 & 29-kDa ribonucleoprotein A (chloroplast precursor) & -2.57 & -3.09 & -2.00 & -2.95 & -2.52 \\
\hline AK068441 & Chloroplast nucleoid DNA-binding protein & -2.52 & -2.68 & -3.11 & -2.51 & -2.02 \\
\hline AK062941 & 33-kDa oxygen-evolving protein of photosystem II & -2.48 & -3.00 & -2.19 & -2.94 & -2.06 \\
\hline AK100602 & Rubisco subunit binding-protein ( $\alpha$ subunit) & -2.45 & -2.93 & -1.92 & -2.79 & -2.44 \\
\hline AK061410 & Rubisco subunit binding-protein ( $\alpha$ subunit) & -2.19 & -2.26 & -2.00 & -2.55 & -2.02 \\
\hline AK070391 & Coproporphyrinogen III oxidase (chloroplast precursor) & -2.14 & -2.15 & -2.14 & -2.15 & -2.12 \\
\hline AK060024 & 50S ribosomal protein L24 (chloroplast precursor) & -3.71 & -3.67 & -3.40 & -3.79 & -4.01 \\
\hline AK070779 & 50S ribosomal protein L5 (chloroplast precursor) & -2.87 & -3.14 & -2.28 & -3.21 & -3.07 \\
\hline AK071751 & 50S ribosomal protein L9 (chloroplast precursor) & -2.38 & -2.39 & -2.28 & -2.52 & -2.37 \\
\hline AK099849 & 50S ribosomal protein L3 (chloroplast precursor) & -2.37 & -2.43 & -2.25 & -2.63 & -2.22 \\
\hline AK058369 & 50S ribosomal protein L9 (chloroplast precursor) & -2.36 & -2.27 & -2.30 & -2.45 & -2.44 \\
\hline AK104424 & 50S ribosomal protein L4 (chloroplast precursor) & -2.34 & -2.17 & -2.77 & -2.28 & -2.24 \\
\hline AK066837 & 50S ribosomal protein L35 (chloroplast precursor) & -2.15 & -2.09 & -2.22 & -2.30 & -2.01 \\
\hline AK062182 & 50S ribosomal protein L21 (chloroplast precursor) & -2.13 & -2.25 & -2.00 & -2.11 & -2.16 \\
\hline AK066527 & 50S ribosomal protein L15 (chloroplast precursor) & -2.13 & -2.21 & -2.05 & -2.07 & -2.18 \\
\hline AK067481 & 50S ribosomal protein L28 (chloroplast precursor) & -2.00 & -2.14 & -1.82 & -2.03 & -2.02 \\
\hline AK099298 & 30S ribosomal protein S17 (chloroplast precursor) & -2.70 & -2.83 & -2.43 & -3.02 & -2.61 \\
\hline AK062461 & 30 S ribosomal protein 2 (chloroplast precursor) & -2.00 & -2.04 & -1.68 & -2.19 & -2.21 \\
\hline
\end{tabular}

${ }^{\text {a }}$ Fold change $=($ normalized signal intensity of mock inoculated $) /($ normalized signal intensity of RDV infected $)$

Table 4. Defense- and stress-related genes whose expression was enhanced by Rice dwarf virus (RDV) 9 days after inoculation of rice plants

\begin{tabular}{|c|c|c|c|c|c|c|}
\hline \multirow[b]{2}{*}{ Classification, GenBank no. } & \multirow[b]{2}{*}{ Annotation } & \multicolumn{5}{|c|}{ Fold change $^{a}$} \\
\hline & & Ave. & Slide 1 & Slide 2 & Slide 3 & Slide 4 \\
\hline \multicolumn{7}{|l|}{ PR proteins ${ }^{\mathrm{b}}$} \\
\hline AK071613 & Probenazole-inducible protein PBZ1 & 9.74 & 9.86 & 8.82 & 8.62 & 11.66 \\
\hline AK107926 & PR1 & 4.20 & 4.74 & 4.85 & 4.04 & 3.16 \\
\hline AK070056 & $\beta$ 1,3-Glucanase & 7.49 & 6.44 & 5.70 & 10.01 & 7.83 \\
\hline AK104862 & $\beta$ 1,3-Glucanase & 4.25 & 4.40 & 4.55 & 5.34 & 2.74 \\
\hline AK104472 & $\beta$ 1,3-Glucanase & 2.91 & 3.46 & 2.90 & 3.68 & 1.61 \\
\hline AK071889 & $\beta$ 1,3-Glucanase & 2.62 & 2.56 & 3.68 & 2.56 & 1.67 \\
\hline AK067528 & $\beta$ 1,3-Glucanase & 2.12 & 2.44 & 2.45 & 2.19 & 1.40 \\
\hline AK061042 & Chitinase & 7.28 & 8.70 & 11.35 & 5.58 & 3.48 \\
\hline AK060363 & Chitinase IIb & 5.82 & 5.70 & 4.13 & 7.59 & 5.88 \\
\hline AK071013 & Chitinase IIb & 5.01 & 3.84 & 3.68 & 6.89 & 5.62 \\
\hline AK100973 & Chitinase acidic class III & 4.19 & 5.00 & 4.42 & 3.63 & 3.70 \\
\hline AK059767 & Chitinase & 4.01 & 4.55 & 4.36 & 3.90 & 3.22 \\
\hline AK102505 & Chitinase class III & 3.40 & 4.78 & 3.08 & 3.47 & 2.27 \\
\hline AK099355 & Chitinase & 2.64 & 3.08 & 2.94 & 2.61 & 1.92 \\
\hline AK060033 & Chitinase class III & 2.01 & 1.69 & 1.53 & 2.64 & 2.16 \\
\hline AK106178 & Chitinase & 2.00 & 1.82 & 2.43 & 2.17 & 1.59 \\
\hline AK063234 & PR 4 protein & 2.74 & 3.25 & 3.24 & 2.47 & 2.01 \\
\hline AK102970 & Thaumatin-like protein & 3.15 & 3.49 & 3.40 & 3.72 & 2.01 \\
\hline \multicolumn{7}{|l|}{ WRKY transcription factors } \\
\hline AK108522 & WRKY transcription factor 67 & 3.61 & 3.57 & 3.46 & 3.69 & 3.71 \\
\hline AK101653 & WRKY transcription factor 55 & 2.94 & 2.98 & 3.37 & 2.85 & 2.55 \\
\hline AK103696 & WRKY domain containing-protein & 2.80 & 3.38 & 3.12 & 2.54 & 2.16 \\
\hline AK109568 & WRKY transcription factor 34 & 2.01 & 2.32 & 2.13 & 2.04 & 1.57 \\
\hline \multicolumn{7}{|l|}{ Stress-response proteins } \\
\hline AK064650 & Glutathione S-transferase 20 & 2.98 & 3.10 & 3.04 & 2.31 & 3.45 \\
\hline AK108376 & Glutathione S-transferase 12 & 2.54 & 3.06 & 2.59 & 2.13 & 2.38 \\
\hline AK107822 & Glutathione S-transferase 29 & 2.20 & 1.98 & 2.14 & 2.35 & 2.34 \\
\hline AK067416 & Peroxidase & 20.02 & 18.33 & 19.94 & 23.52 & 18.29 \\
\hline AK073202 & Peroxidase (POX22.3) & 2.74 & 2.83 & 3.05 & 2.59 & 2.50 \\
\hline AK069456 & Peroxidase & 2.60 & 2.91 & 2.28 & 2.77 & 2.43 \\
\hline AK068186 & Heat-shock protein (DnaJ family) & 3.56 & 3.70 & 4.85 & 2.30 & 3.38 \\
\hline AK064436 & Heat shock-protein (HSP101) & 3.48 & 3.94 & 3.48 & 2.93 & 3.59 \\
\hline AK071240 & 18-kDa heat-shock protein & 2.06 & 2.11 & 1.85 & 1.67 & 2.59 \\
\hline
\end{tabular}

${ }^{\text {a }}$ Fold change, (normalized signal intensity of RDV infected) / (normalized signal intensity of mock inoculated).

${ }^{\mathrm{b}} \mathrm{PR}=$ pathogenesis-related. 
our result. Both gibberellin and brassinosteroid are important determinants of plant height. Thus, repression of the OsDWARF gene might explain the stunting of rice plants infected with RDV.

We anticipated changes in levels of expression of chloroplast-related genes because a typical symptom of RDVinfected rice plants is the appearance of numerous white chlorotic specks on plant leaves (Fig. 1). As we had suspected, expression of many plastid-related genes, such as genes for chlorophyll $\mathrm{a} / \mathrm{b}$-binding protein and the $\alpha$ subunit of rubisco subunit binding-protein, was repressed. This change could lead to lower levels of expression of the proteins required for photosynthesis and result in suppressed cell growth, leading eventually to stunting and a decrease in grain yield.

Comparison of our results with gene-expression profiles from other systems revealed a number of similarities in terms of the types of gene whose expression changes in response to viral infection. The most significant similarities were apparent for defense- and stress-related genes, such as genes for PR1, $\beta$ 1,3-glucanases, chitinases, thaumatin-like protein, glutathione $S$-transferase, heat-shock protein (HSP) 101, and small HSP, and for transcription factors, such as the WRKY DNA-binding protein (Table 4). Thus, it is likely that rice responds to RDV infection by expressing defense-related genes, as it does when infected with a virus (Ventelon-Debout et al. 2004), a fungus (Kim et al. 2004), and a bacterium (Fujiwara et al. 2004) and as do other plants when infected with viruses (Senthil et al. 2005; Whitham et al. 2003), a viroid (Itaya et al. 2002), fungi (Dowd et al. 2004; Maleck et al. 2000; Moy et al. 2004; Schenk et al. 2000), and bacteria (Tao et al. 2003; Zou et al. 2005). Also, as with previous reports involving diverse plusstrand RNA viruses (e.g., tobamoviruses [Carr et al. 2006; Whitham et al. 2003], Potato virus $X$ potexvirus [Whitham et al. 2003], Cucumber mosaic cucumovirus [Whitham et al. 2003], and Rice yellow mottle sobemovirus [Ventelon-Debout et al. 2004]), and negative-strand RNA viruses (Sunchus yellow net nucleorhabdovirus and Impatiens necrotic spot tospovirus [Senthil et al. 2005]), the expression of stress-related genes was enhanced after infection by RDV, a double-strand RNA phytoreovirus. Our experimental results suggest that expression of many defense- and stress-related genes seems to be a common response in compatible plant-virus interactions regardless of monocotyledon or dicotyledon. Detailed studies on
HSP 101, one of the stress-related proteins, showed that the expression of HSP $101 \mathrm{mRNA}$ in response to tobamovirus infection was enhanced; however, this protein did not have an exact effect on the efficiency of tobamovirus infection (Car et al. 2006). Although, in rice, relatively little is known about the expression pathways of the stress-related genes and roles of their products, our experimental results might be useful in a resolution of those in rice.

The work presented here described gene expression changes in rice infected with RDV on the whole-plant level. Thus, some significant gene expression changes could be masked when they did not occur at sufficient levels or in a small number of specifically responding cells. Our results indicate that, when a rice plant is infected with RDV, photosynthetic and cell-elongation activities are suppressed and defense-related genes are expressed. Such changes might allow rice plants to survive RDV infection in the wild, permitting the production of seed for the next generation, even though the number of seed produced by RDV-infected rice plants is greatly reduced (data not shown). Some of the genes identified in this study might encode proteins that are critical for viral activity in infected rice plants and might, perhaps, be potential targets for controlling infection of rice plants by RDV. The information from our microarray analysis eventually might lead to the development of rational strategies for the management of rice dwarf disease in rice.

\section{MATERIALS AND METHODS}

Plant growth conditions and inoculation with RDV.

Ten rice seed (Oryza sativa L. cv. Nipponbare) were sown in a pot ( $85 \mathrm{~mm}$ in diameter and $75 \mathrm{~mm}$ in height) that had been filled with approximately $250 \mathrm{ml}$ of commercial soil mixture (Bonsol; Sumitomo Chemical, Osaka, Japan). The pot then was submerged in water inside a container $(53 \mathrm{~cm}$ wide by $35 \mathrm{~cm}$ deep by $6 \mathrm{~cm}$ high) and was kept in a south-facing greenhouse ( $6 \mathrm{~m}$ wide by $5 \mathrm{~m}$ deep by $3 \mathrm{~m}$ high) at $25 \pm 3^{\circ} \mathrm{C}$ under natural sunlight. Nine-day-old 10 rice seedlings were exposed to approximately 50 viruliferous insects or virus-free insects (for mock inoculation) in each of the adjoining inoculation chamber (70 $\mathrm{cm}$ wide by $70 \mathrm{~cm}$ deep by $75 \mathrm{~cm}$ high) in a greenhouse for 1 day. Pots were turned clockwise at a $90^{\circ}$ angle, and insects were gently brushed away from rice plants to obtain a higher

\begin{tabular}{|c|c|c|c|c|c|c|c|c|}
\hline \multicolumn{3}{|l|}{ Enhanced } & \multicolumn{3}{|c|}{ Suppressed } & \multicolumn{3}{|l|}{ Control } \\
\hline Genbank & 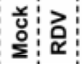 & $\begin{array}{c}\text { Fold } \\
\text { change }\end{array}$ & Genbank & $\begin{array}{l:l}\frac{x}{0} & a \\
\Sigma & \alpha\end{array}$ & $\begin{array}{l}\text { Fold } \\
\text { change }\end{array}$ & Genbank & 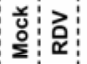 & $\begin{array}{l}\text { Fold } \\
\text { change }\end{array}$ \\
\hline AK073592 & & 26.3 & AK062795 & $=$ & -64.6 & AK068316 & $=$ & 1.01 \\
\hline AK107688 & & 24.1 & AK071989 & 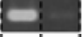 & -37.2 & AK102190 & $-i$ & 1.08 \\
\hline AK067416 & & 20.0 & AK065284 & 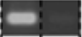 & -31.7 & AK104191 & $-=$ & 1.08 \\
\hline AK071613 & & 9.7 & AK058218 & E & -27.7 & & & \\
\hline AK070056 & -1 & 7.5 & AK060340 & 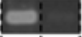 & -20.7 & & & \\
\hline AK099946 & & 7.5 & AK101782 & $\theta$ & -15.3 & & & \\
\hline AK060363 & E & 5.8 & AK061301 & $\theta$ & -12.4 & & & \\
\hline AK107926 & 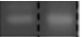 & 4.2 & АK067424 & 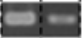 & -8.3 & & & \\
\hline
\end{tabular}

Fig. 3. Analysis by reverse-transcription polymerase chain reaction of the expression of randomly selected genes whose expression appeared, in microarray analysis, to have been affected by Rice dwarf virus (RDV) and of control genes whose expression was unaffected. Mock $=$ mRNA from mock-inoculated rice plants; RDV = mRNA from RDV-infected rice plants; Fold change in enhanced and control = the average of the change (RDV infection/mock inoculation) in the level of expression from four sets of microarray data; Fold change in suppressed = the average of the change (mock inoculation/RDV infection) in the level of expression from four sets of microarray data. 
infection rate. After insects were removed completely from the plants by gentle brushing, the inoculated plants were taken out of the inoculation chamber. Then, the inoculated plants were grown in the same container in the insect-free greenhouse at 25 $\pm 3^{\circ} \mathrm{C}$ under natural sunlight until early symptoms appeared on infected plants. Position of the RDV-inoculated and mockinoculated plants were changed in each of biological replicates shown in Table 1. Aerial parts of whole plants were harvested 9 dpi, a time when the first newly developed leaf with symptoms appeared, flash-frozen immediately in liquid nitrogen, and stored at $-80^{\circ} \mathrm{C}$. For each inoculation, three additional plants were kept for typical symptom observation until 20 dpi. Four biological replicates of these experiments were performed (Table 1). As described above, RDV-infected and mock-inoculated plants were handled with careful attention to eliminate the possibility of chamber effects or position effects.

\section{Extraction of RNA and microarray analysis.}

Total RNA was extracted from RDV-infected and mockinoculated plants. In brief, 10 frozen plants (approximately 2.0 g) were homogenized with a mortar and pestle in liquid nitrogen. The ground powder was transferred to a polypropylene tube, and then total RNA was purified with an RNeasy Maxi kit (Qiagen, Valencia, CA, U.S.A.). Samples were checked with a BioAnalyzer 2100 (Agilent Technologies, Palo Alto, CA, U.S.A.) to verify that RNA remained intact, and the concentration of RNA in each sample was determined with a spectrophotometer (Nanodrop ND-1000; NanoDrop Technologies, Wilmington, DE, U.S.A.).

For microarray analysis, total RNA was processed for hybridization to Agilent $22 \mathrm{~K}$ rice oligo DNA arrays (Agilent Technologies) according to the manufacturer's protocol. In brief, $0.5 \mu \mathrm{g}$ of total RNA was used as substrate for reverse transcription by MMLV reverse transcriptase to generate doublestranded cDNA, with an oligo $(\mathrm{dT})_{24}$ primer fused to the T7 RNA polymerase promoter. After synthesis of cDNA, complementary RNA (cRNA) was transcribed by T7 RNA polymerase to generate cyanine3 (Cy3; PerkinElmer, Wellesley, MA, U.S.A.)- or cyanine5 (Cy5; PerkinElmer)-labeled RNAs. After purification and fragmentation, $1 \mu \mathrm{g}$ of $\mathrm{Cy} 3-$ and $1 \mu \mathrm{g}$ of Cy5labeled cRNA was used in a hybridization mixture that contained added hybridization controls. A total of $500 \mu$ l of the mixture was used for hybridization on arrays for $17 \mathrm{~h}$ at $60^{\circ} \mathrm{C}$.

After standard post-hybridization washing, the fluorescence intensities at the targets were detected by an Agilent DNA microarray scanner (model G2565BA; Agilent Technologies), and resulting images were processed using the Feature Extraction software (version 8.1.1.1; Agilent Technologies). This included defining the spots, measuring intensities, flagging spots with inadequate measurements, subtracting local background, and LOWESS dye normalization. Spots that did not pass quality control procedures in this software were flagged and removed from further analysis. A possible dye bias was eliminated using an algorithm for the same extraction software (Feature Extraction software DyeNorm algorithm; Agilent Technologies) that applies normalization factors. For spots that were not flagged as having inadequate measurements, we calculated the average ratio of expression of each spot after dividing the normalized signal intensity of mRNA from RDV-infected plant by the normalized signal intensity of that from mock-inoculated plants. All the expression profiles are available as Gene Series 5286 (GSE5286) in the Gene Expression Omnibus (GEO) at the National Center for Biotechnology Information (NCBI).

\section{Metabolic pathway analysis.}

From RiceCyc in GRAMENE (Jaiswal et al., 2006), we downloaded metabolic pathway-associated genes whose ID was given by the sequence information of TIGR Locus ID; therefore, those genes did not correspond to the genes spotted in the 22,000 array. Thus, the information of the 22,000 array spotted genes was downloaded from KOME (Rice Full-Length cDNA Consortium, 2004), compared with the genes in TIGR Locus ID, and it was found that 1,756 metabolic pathway-associated genes exist in the 22,000 array. The number of genes influenced by viral infection in different pathways was examined.

\section{RT-PCR.}

Total RNA used for verification of microarray data by RTPCR was prepared from plants that had been grown independently of those used for isolation of RNA for microarray analysis. After removal of DNA by RNase-free DNase (Qiagen), total RNA was reverse transcribed in a $20-\mu$ l reaction mixture that contained SuperScript III (Invitrogen, Carlsbad, CA, U.S.A.) with an oligo $(\mathrm{dT})_{20}$ primer at $50^{\circ} \mathrm{C}$ for $50 \mathrm{~min}$. After termination of the reaction by heating at $70^{\circ} \mathrm{C}$ for $15 \mathrm{~min}$, the final reaction mixture was diluted in water to a volume of 100 $\mu \mathrm{l}$. For amplification by PCR, $1 \mu \mathrm{l}$ of the solution of cDNA was used as the source of the template. PCR was performed in $10 \mu \mathrm{l}$ of a reaction mixture that contained 0.5 unit of exTaq DNA polymerase (Takara, Kyoto, Japan) and 20 pmol of each primer. The program for PCR was as follows: incubation for 1 min at $94^{\circ} \mathrm{C} ; 24$ to 40 cycles of incubation for $15 \mathrm{~s}$ at $94^{\circ} \mathrm{C}$, for $15 \mathrm{~s}$ at $55^{\circ} \mathrm{C}$, and for $15 \mathrm{~s}$ at $72^{\circ} \mathrm{C}$; and incubation for $5 \mathrm{~min}$ at $72^{\circ} \mathrm{C}$.

\section{Anatomical observations.}

For anatomical studies, we used RDV-infected plants 20 dpi. The leaf sheaths just under the fourth leaf were sectioned with a razor blade. We examined sections under a light microscope and took photographs with a digital camera (EOS 20D; Canon, Tokyo). Color conversion of the photographs was performed using Adobe Photoshop 7.0 (Adobe Systems, San Jose, CA, U.S.A.).

\section{ACKNOWLEDGMENTS}

This project was supported by a Research Fellowship for Young Scientists (no. 16.1768 to T. Shimizu) from the Japan Society for the Promotion of Science and by a Grant-in-Aid for Scientific Research (no. B.15380038 to T. Omura) from the Japan Society for the Promotion of Science.

\section{LITERATURE CITED}

Arabidopsis Genome Initiative. 2000. Analysis of the genome sequence of the flowering plant Arabidopsis thaliana. Nature 408:796-815.

Aranda, M. A., Escaler, M., Wang, D., and Maule, A. J. 1996. Induction of HSP70 and polyubiquitin expression associated with plant virus replication. Proc. Natl. Acad. Sci. U.S.A. 93:15289-15293.

Baumberger, N., Ringli, C., and Keller, B. 2001. The chimeric leucine-rich repeat/extensin cell wall protein LRX1 is required for root hair morphogenesis in Arabidopsis thaliana. Genes Dev. 15:1128-1139.

Carr, T., Wang, Y., Huang, Z., Yeakley, J. M., Fan, J.-B, and Whitham, S. A. 2006. Tobamovirus infection is independent of HSP101 mRNA induction and protein expression. Virus Res. 121:33-41.

Dowd, C., Wilson, I. W., and McFadden, H. 2004. Gene expression profile changes in cotton root and hypocotyl tissues in response to infection with Fusarium oxysporum f. sp. vasinfectum. Mol. Plant-Microbe Interact. 17:654-667.

Escaler, M., Aranda, M. A., Thomas, C. L., and Maule, A. J. 2000. Pea embryonic tissues show common responses to the replication of a wide range of viruses. Virology 267:318-325.

Fujiwara, S., Tanaka, N., Kaneda, T., Takayama, S., Isogai, A., and Che, F. S. 2004. Rice cDNA microarray-based gene expression profiling of the response to flagellin perception in cultured rice cells. Mol. PlantMicrobe Interact. 17:986-998.

Golem, S., and Culver, J. N. 2003. Tobacco mosaic virus induced alterations in the gene expression profile of Arabidopsis thaliana. Mol. PlantMicrobe Interact. 16:681-688. 
Hagiwara, K., Higashi, T., Miyazaki, N., Naitow, H., Cheng, R. H., Nakagawa, A., Mizuno, H., Tsukihara, T., and Omura, T. 2004. The amino-terminal region of major capsid protein P3 is essential for selfassembly of single-shelled core-like particles of Rice dwarf virus. J. Virol. 78:3145-3148.

Havelda, Z., and Maule, A. J. 2000. Complex spatial responses to Cucumber mosaic virus infection in susceptible Cucurbita pepo cotyledons. Plant Cell 12:1975-1986.

Hong, Z., Ueguchi-Tanaka, M., Shimizu-Sato, S., Inukai, Y., Fujioka, S., Shimada, Y., Takatsuto, S., Agetsuma, M., Yoshida, S., Watanabe, Y., Uozu, S., Kitano, H., Ashikari, M., and Matsuoka, M. 2002. Loss-offunction of a rice brassinosteroid biosynthetic enzyme, C-6 oxidase, prevents the organized arrangement and polar elongation of cells in the leaves and stem. Plant J. 32:495-508.

Hull, R. 2002. Matthew's Plant Virology, 4th ed. Academic Press, New York.

International Rice Genome Sequencing Project. 2005. The map-based sequence of the rice genome. Nature 436:793-800.

Itaya, A., Matsuda, Y., Gonzales, R. A., Nelson, R. S., and Ding, B. 2002. Potato spindle tuber viroid strains of different pathogenicity induces and suppresses expression of common and unique genes in infected tomato. Mol. Plant-Microbe Interact. 15:990-999.

Jaiswal, P., Ni, J., Yap, I., Ware, D., Spooner, W., Youens-Clark, K., Ren, L., Liang, C., Zhao, W., Ratnapu, K., Faga, B., Canaran, P., Fogleman, M., Hebbard, C., Avraham, S., Schmidt, S., Casstevens, T. M., Buckler, E. S., Stein, L., and McCouch, S. 2006. Gramene: a bird's eye view of cereal genomes. Nucleic Acids Res. 34:D717-D723.

Kim, S. T., Kim, S. G., Hwang, D. H., Kang, S. Y., Kim, H. J., Lee, B. H., Lee, J. J., and Kang, K. Y. 2004. Proteomic analysis of pathogen-responsive proteins from rice leaves induced by rice blast fungus, Magnaporthe grisea. Proteomics 4:3569-3578.

Maleck, K., Levine, A., Eulgem, T., Morgan, A., Schmid, J., Lawton, K. A., Dangl, J. L., and Dietrich, R. A. 2000. The transcriptome of Arabidopsis thaliana during systemic acquired resistance. Nat. Genet. 26:403-410.

Marathe, R., Guan, Z., Anandalakshmi, R., Zhao, H., and Dinesh-Kumar, S. P. 2004. Study of Arabidopsis thaliana resistome in response to cucumber mosaic virus infection using whole genome microarray. Plant Mol. Biol. 55:501-520.

Maule, A., Leh, V., and Lederer, C. 2002. The dialogue between viruses and hosts in compatible interactions. Curr. Opin. Plant Biol. 5:279-284.

Miyazaki, N., Hagiwara, K., Naitow, H., Higashi, T., Cheng, R. H., Tsukihara, T., Nakagawa, A., and Omura, T. 2005. Transcapsidation and the conserved interactions of two major structural proteins of a pair of phytoreoviruses confirm the mechanism of assembly of the outer capsid layer. J. Mol. Biol. 345:229-237.

Mori, M., Nomura, T., Ooka, H., Ishizaka, M., Yokota, T., Sugimoto, K., Okabe, K., Kajiwara, H., Satoh, K., Yamamoto, K., Hirochika, H., and Kikuchi, S. 2002. Isolation and characterization of a rice dwarf mutant with a defect in brassinosteroid biosynthesis. Plant Physiol. 130:11521161.

Moy, P., Qutob, D., Chapman, B. P., Atkinson, I., and Gijzen, M. 2004. Patterns of gene expression upon infection of soybean plants by Phytophthora sojae. Mol. Plant-Microbe Interact. 17:1051-1062.

Nakagawa, A., Miyazaki, N., Taka, J., Naitow, H., Ogawa, A., Fujimoto, Z., Mizuno, H., Higashi, T., Watanabe, Y., Omura, T., Cheng, R. H., and Tsukihara, T. 2003. The atomic structure of Rice dwarf virus reveals the self-assembly mechanism of component proteins. Structure 11:12271238.

Omura, T., and Yan, J. 1999. Role of outer capsid proteins in transmission of Phytoreovirus by insect vectors. Adv. Virus Res. 54:15-43.

Rensink, W. A., and Buell, C. R. 2005. Microarray expression profiling resources for plant genomics. Trends Plant Sci. 10:603-609.

Rice Full-Length cDNA Consortium. 2004. Collection, mapping, and an- notation of over 28,000 cDNA clones from japonica rice. Science 301:376-379

Schenk, P. M., Kazan, K., Wilson, I., Anderson, J. P., Richmond, T., Somerville, S. C., and Manners, J. M. 2000. Coordinated plant defense responses in Arabidopsis revealed by microarray analysis. Proc. Natl. Acad. Sci. U.S.A. 97:11655-11660.

Senthil, G., Liu, H., Puram, V. G., Clark, A., Stromberg, A., and Goodin, M. M. 2005. Specific and common changes in Nicotiana benthamiana gene expression in response to infection by enveloped viruses. J. Gen. Virol. 86:2615-2625.

Somerville, C., Bauer, S., Brininstool, G., Facette, M., Hamann, T., Milne, J., Osborne, E., Paredez, A., Persson, S., Raab, T., Vorwerk, S., and Youngs, H. 2004. Toward a systems approach to understanding plant cell walls. Science 306:2206-2211.

Tao, Y., Xie, Z., Chen, W., Glazebrook, J., Chang, H. S., Han, B., Zhu, T., Zou, G., and Katagiri, F. 2003. Quantitative nature of Arabidopsis responses during compatible and incompatible interactions with the bacterial pathogen Pseudomonas syringae. Plant Cell 15:317-330.

Ventelon-Debout, M., Delalande, F., Brizard, J.-P., Diemer, H., Van Dorsselaer, A., and Brugidou, C. 2004. Proteome analysis of cultivarspecific deregulations of Oryza sativa indica and $O$. sativa japonica cellular suspensions undergoing Rice yellow mottle virus infection. Proteomics 4:216-225.

Wang, D., and Maule, A. J. 1995. Inhibition of host gene expression associated with plant virus replication. Science 267:229-231.

Wei, T., Kikuchi, A., Moriyasu, Y., Suzuki, N., Shimizu, T., Hagiwara, K., Chen, H., Takahashi, M., Ichiki-Uehara, T., and Omura, T. 2006a. The spread of Rice dwarf virus among cells of its insect vector exploits virus-induced tubular structures. J. Virol. 80:8593-8602.

Wei, T., Kikuchi, A., Suzuki, N., Shimizu, T., Hagiwara, K., Chen, H., and Omura, T. 2006b. Pns4 of rice dwarf virus is a phosphoprotein, is localized around the viroplasm matrix, and forms minitubules. Arch. Virol. 151:1701-1712.

Wei, T., Shimizu, T., Hagiwara, K., Kikuchi, A., Moriyasu, Y., Suzuki, N., Chen, H., and Omura, T. 2006c. Pns12 protein of Rice dwarf virus is essential for formation of viroplasms and nucleation of viral-assembly complexes. J. Gen. Virol. 87:429-438.

Whitham, S. A., Quan, S., Chang, H. S., Cooper, B., Estes, B., Zhu, T., Wang, X., and Hou, Y. M. 2003. Diverse RNA viruses elicit the expression of common sets of genes in susceptible Arabidopsis thaliana plants. Plant J. 33:271-283.

Yokoyama, R., and Nishitani, K. 2004. Genomic basis for cell-wall diversity in plants. A comparative approach to gene families in rice and Arabidopsis. Plant Cell Physiol. 45:1111-1121.

Zhu, S., Gao, F., Cao, X., Chen, M., Ye, G., Wei, C., and Li, Y. 2005. The Rice dwarf virus $\mathrm{P} 2$ protein interacts with ent-kaurene oxidases in vivo, leading to reduced biosynthesis of gibberellins and rice dwarf symptoms. Plant Physiol. 139:1935-1945.

Zou, J., Rodriguez-Zas, S., Aldea, M., Li, M., Zhu, J., Gonzalez, D. O., Vodkin, L. O., DeLucia, E., and Clough, S. J. 2005. Expression profiling soybean response to Pseudomonas syringae reveals new defenserelated genes and rapid HR-specific downregulation of photosynthesis. Mol. Plant-Microbe Interact. 18:1161-1174.

\section{AUTHOR-RECOMMENDED INTERNET RESOURCES}

The KOME (Knowledge-based Oryza Molecular biological Encyclopedia) Oryza sativa database: cdna01.dna.affrc.go.jp/cDNA

GRAMENE (a resource for comparative grass genomics): www.gramene.org/

GRAMENE RiceCyc website: www.gramene.org/pathway/

National Center for Biotechnology Information Gene Expression Omnibus website: www.ncbi.nlm.nih.gov/geo/ 